------ Raf. J. Sci., Vol. 22, No.3 pp 11- 20, 2011-----

\title{
Antibacterial Activity of Water and Alcoholic Crude Extract of Flower Achillea millefolium
}

\author{
Rasha N. Hasson \\ Department of Biology \\ College of Education for Girls \\ Mosul University
}

(Received 16/1/2011; Accepted 4/4/2011)

\begin{abstract}
The aim of this study was to determine the antimicrobial effect of yarrow and it is flower extract on certain microorganisms. The ethanolic (alcoholic) extract of the flower and aqueous (water) extract was tested against: Pseudomonasa aeruginosa, Salmonella enterica enterica (Typhimurium), Shigella flexneri, Micrococcus luteus, Staphylococcus aureus and Enterococcus faecalis. Using the diffusion test, the alcoholic and aqueous flower extract at $200 \mathrm{mg} / \mathrm{ml}$ possessed abroad spectrum of antimicrobial activity against all tested microorganisms at different conc., alcoholic extract had the greatest inhibitory effect (diameter of inhibition zone) against Pseudo. aeruginosa $30 \mathrm{~mm}$, Staph. aureus $24 \mathrm{~mm}$ and Micro. lutues $23 \mathrm{~mm}$, While the aqueous extract slightly inhibited Pseudomonasa aeruginosa and Micrococcus luteus $12 \mathrm{~mm}$ and $10 \mathrm{~mm}$ respectively compared with standard antibiotic Ciprofloxacin $26 \mathrm{~mm}, 22 \mathrm{~mm}$ and $22 \mathrm{~mm}$ but Entero. faecalis, S. enterica enterica (Typhimurium) and Shig. flexneri show high resistance for both extract $8 \mathrm{~mm}, 0 \mathrm{~mm}, 9 \mathrm{~mm}$, $12 \mathrm{~mm}$ and $8 \mathrm{~mm}, 10 \mathrm{~mm}$ but sensitivity for Ciprofloxacin $23 \mathrm{~mm}, 30 \mathrm{~mm}$ and $31 \mathrm{~mm}$. Minimum inhibitory concentration (MIC) were determined for alcoholic extract against sensitivite microorganisms: Pseudo. aeruginosa $50 \mathrm{mg} / \mathrm{ml}$, Staph. aureus $100 \mathrm{mg} / \mathrm{ml}$ and Micro. luteus $100 \mathrm{mg} / \mathrm{ml}$. It could be concluded that the alcoholic extract of yarrow flower have considerable antimicrobial effect on some pathogenic which cause infection.
\end{abstract}

Keywords: Achillea millefolium, antimicrobial activity, ethanol extract, aqueous extract, yarrow, antibiotic.

\section{الهمالية المضادة للجراثيم للمستخلص المائي والكحول الخلم لأزهار الخيلية (لم اله ورقة)}

\section{الملغص}

هذفت الدرلسة إلى إظظهار فعالية الخيلية بوصفها مضادأ للجراثيم وتحديد تأثير مستخلصت الأزهار

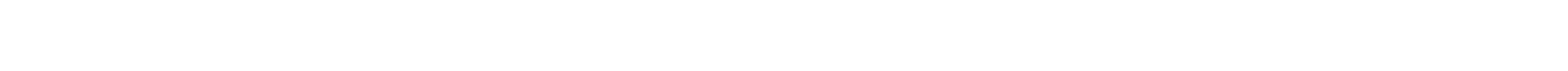

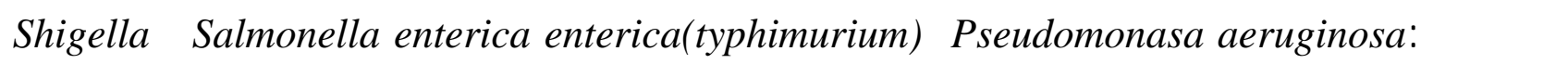
Enterococcus faecalis Staphylococcus aureus ،Micrococcus luteus, flexneri 


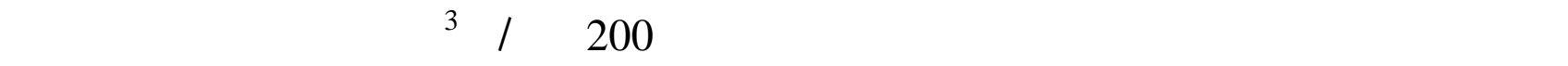
المضادة لنمو جمبع الجراثيم المستخمة في الاختبار وبشكل مقاوت فكان المستخلص الكحولي الأكثر تاثيرا اذ كلن (قطرمطقة التبيط) للك من الجراثيم : Pseudo. aeruginosa 23 Micro. luteus 12 Micrococcus luteus Pseudomonasa aeruginosa S. enterica Entero. faecalis الحيوي القيلسي Ciprofloxacin: 26ملم، 22ملم و 22:

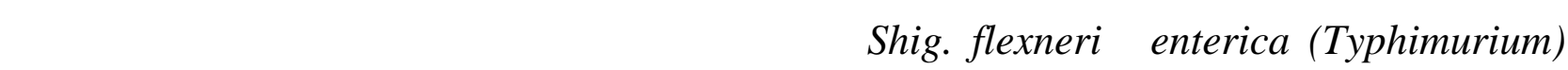
التبط 8ملم و0ملم، 9ملم و2املم و 8ملم و10ملم فيما لظٔهرت هذه الجراثيم جسلسية عالية للمضاد الحيوي وباقطارتشيط بلغت 30ملم ، 30ملم و 310iprofloxacin

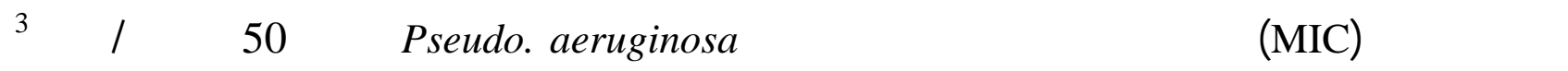
100 100 Staph. aureus، الكحولي لازهارالخيلية كلن له تأثير فعل مضاد لنمو بعض الممرضمات التي تسبب التهابلت.

الكاملت الدالة: لخيلية لُ ألف ورقة، الفعالية المضادة للجراثيم، مستخلص كحولي، مستخلص مائي، عثبة الجروح، مضاد حيوي.

\section{INTRODUCTION}

Plants, a source of medicinal compounds have continued to play a dominant role in maintenance of human health since ancient times. The World Health Organization estimates that plant extracts or their active constituents were used as folk medicine in traditional therapies of $80 \%$ of the world population (Anonynous, 1993). Over $50 \%$ of all modern clinical drugs are of natural origin (Baker et al., 1995). Iraqi People have traditionally used a number of plants species for treatment of infections disease and various ailments (Najla and Awaz, 2009).

The treatment of infectious diseases with antimicrobial agents continues to present problems in modern day, medical studies showed a significant increase in the incidence of side effects and the resistance that pathogenic microorganisms build against several antibiotic (Kunin, 1993; Finch, 1998; Iwu, 1999; Nascimento, 2000). However attention has been paid to plant and biologically active compounds isolated from them used in herbal medicine such as alkaloids, flavonoids, isoflavonoids, tannins,glycosides and phenolic compounds (Evans et al., 2002; Romero, 2005).

Plants with possible antimicrobial activity should be tested against an appropriate microbial model to confirm its activity (Nair et al.,2005). The effect of plant extracts on microorganisms have been studied by a number of researcher in different parts of the world (Mahansen, 1996 ; Kivcak et al., 2002 : Uzan et al., 2002 : Ates and Erdogrul , 2003 
;Barbour et al., 2004; Kirbag et al., 2005 ; Sengul and Ogutcu, 2005; Dulger et al., 2005; Kumar et al., 2006 ; Mathabe et al., 2006).

Achillea Millefolium L. (Yarrow) is flowering plant in the family Achillea Asteraceae grows in Europe, North America and Asia. a number of species were used as garden omamentals. The aerial parts of yarrow have along history of traditional herb medicine in veterinary medicine (Ludwing, 1996; Hirti, 2000). Preparation in the form of decoctions or fresh juices have applied against anorexia, stomach, cramps, flatulence, gastritis, enteritis, internal and external bleeding (bloody cough, nosebleed, and menstrual bleeding, bloody urine), wounds, sores, skin rash as well as dog and snake bite sites. Its name is derived from Achilles (means a mythical character), who carried it with his army to treat the wounds of his fellow soldiers during Trojan war, its specific name means (a thousand leaves) and refers to its shape like bird feather. This medicinal utillsation is also reflected in some of its common name: wound wort A, nosebleed, blood wort, sanguinar, herb milltaris and knights milfoil (Chandler et al., 1982).

The genus Achillea consists of 140 perennial herbs native to the northern hemispheres. Yarrow (fig. 1) aerial parts of the Achillea which has the widest range of herb applications in the world, it contains a volatile oil rich in sesquiterpene lactones and alkaloids (Muller et al., 1994). In vitro studies yarrow flower extract showed its antimicrobial activity to be more effective against certain microorganisms than yarrow leaves and stems (Chandler et al., 1982; Bisset, 1994; Pattnak, 1997; Nemeth and Bernath, 2008).

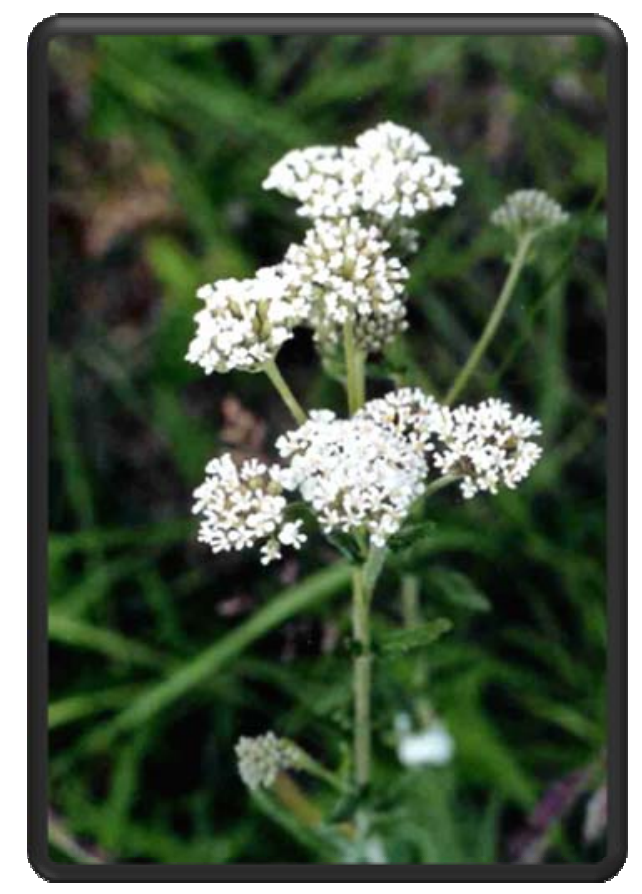

Fig.1: Achillea Millefolium (aerial parts)

(Chandler et al., 1982)

Many plants in Mosul city are familiar and widely used medicinal applications or have the potential to cure some diseases. Yet, these plant do not receive enough assessment therefore this study was conducted to determine the antibacterial activity of yarrow flower against some gram positive and gram negative bacteria. 


\section{MATERIAL AND METHOD}

Plant: Dried yarrow flower were collected from Mosul herbal herbarium and identified according to the relevant literature (The complete medicinal herb) by herbalist in College of Agriculture, Mosul University (Penlope, 1999).

Test microorganisms: Six Bacteria: Pseudo. aeruginosa, S. enterica enterica (Typhimurium)( Tindall et al., 2005; WHO, 2010), Shig. flexneri, Micro. luteus, Staph. aureus and Entero. faecalis provided by Mosul University College of Science, Department of Biology, Identification of bacterial species was confirmed using API Staph. and API Enterobacteracea (Collee et al., 1996), The bacteria were isolated from clinical specimens.

Extract preparation: $10 \mathrm{gm}$ of dried powder of yarrow flower was suspended in 150 $\mathrm{ml}$ of distilled water or absolute ethanol stirred on magnetic stirrer without heating until mixing well. then the mixture was left in refrigerator at $4 \mathrm{C}^{\circ}$ for $24 \mathrm{hr}$ after that both infusions were filtered through many layers of gauze and by using Whatman No.1 filter paper, after drying the two samples of dried extract weighted and stored at $4 \mathrm{C}^{\circ}$ in dark bottles with aluminum foil to prevent negative effect of light (Al - Joboory and Al Rawi,1994). Two sample stock solutions were prepared by suspending $1 \mathrm{gm}$ of dried extract in $5 \mathrm{ml}$ of distilled water or dimethyl sulfoxide for aqueous and alcoholic extract respectively $200 \mathrm{mg} / \mathrm{ml}$, then aqueous stock solution was sterilized by membrane filter o.22 $\mu$ but alcoholic stock solution was sterilized by pasteurization at $62 \mathrm{C}^{0}$ for $10 \mathrm{~min}$. (Al-Neman ,1998). Then tested against all microorganisms, compared with standard antibiotic Ciprofloxacin $5 \mu \mathrm{g} / \mathrm{ml}$, the filter paper disks were impregnated into extract and antibiotic solution (Collee et al., 1996).

Preparation of microbial cultures: The six bacteria were inoculated on nutrient broth incubated for 24hr., bacteria were inoculated in sterile Mueller Hinton agar $\left(10^{8} \mathrm{CFU} / \mathrm{ml}\right)$. Discs were applied on the surface agar medium by pressing slightly Petri dishes and then incubated at $35 \mathrm{C}^{\circ}$ for $24 \mathrm{hr}$. at the end of period, inhibition zones were measured in millimeters (Collins and Lyne, 1987).

Determination of MIC: the MIC for alcoholic extract showed highest antimicrobial effect, Dilution were prepared at concentration $150 \mathrm{mg} / \mathrm{ml}, 100 \mathrm{mg} / \mathrm{ml}, 50 \mathrm{mg} / \mathrm{ml}$ and $25 \mathrm{mg} / \mathrm{ml}$ for sensitive microorganisms (Atlas et al., 1995).

\section{RESULTS AND DISCUSSION}

In vitro antimicrobial activity of the aqueous and alcoholic extracts of yarrow flower $200 \mathrm{mg} / \mathrm{ml}$ was tested against three species of Gram -negative bacteria (Pseudo. aeruginosa, S. enterica enterica (Typhimurium) and Shig. flexneri) and three Gram positive species (Micro. luteus, Staph. aureus and Entero. faecalis) compared with standard antibiotic ciprofloxacin $5 \mu \mathrm{g} / \mathrm{ml}$ was shown in Table.1 and Fig.2. 
Table 1: Antibacterial activity of yarrow flower extract.

\begin{tabular}{|c|c|c|c|}
\hline \multirow{2}{*}{ Microorganisms } & $\begin{array}{c}\text { Alcoholic } \\
\mathbf{( 2 0 0} \\
\mathbf{m g} / \mathbf{m L})\end{array}$ & $\begin{array}{c}\text { Aqueous } \\
\mathbf{( 2 0 0} \mathbf{~ m g} / \mathbf{m L})\end{array}$ & $\begin{array}{c}\text { Ciprofloxacin } \\
\mathbf{( 5 ~} \mathbf{~ g} / \mathbf{m L})\end{array}$ \\
\cline { 2 - 4 } Salmonella enterica enterica (typhimurium) & 9 & 12 & 30 \\
\hline Diameter of zone of inhibition (mm) \\
\hline Shigella flexneri & 8 & 10 & 31 \\
\hline Pseudomonas aeruginosa & 30 & 12 & 26 \\
\hline Staphylococcus aureus & 24 & - & 22 \\
\hline Enterococcus faecalis & 8 & - & 23 \\
\hline Micrococcus luteus & 23 & 10 & 22 \\
\hline
\end{tabular}

(-): No inhibition zone.

The alcoholic and aqueous flower extract of yarrow possessed a board spectrum of antimicrobial activity using the Kirby - Bauer disk diffusion test against all tested microorganisms at different raties, alcoholic extract had the greatest inhibitory effect (diameter of zone of inhibition) against Pseudo. aeruginosa $30 \mathrm{~mm}$ (1), Staph. aureus 24mm (2), and Micro. lutues $23 \mathrm{~mm}$ (3), while the aqueous extract slightly inhibited Pseudomonasa aeruginosa and Micrococcus luteus $12 \mathrm{~mm}$ and $10 \mathrm{~mm}$ respectively compared with standard antibiotic Ciprifloxcain $5 \mu \mathrm{g} / \mathrm{ml}: 26 \mathrm{~mm}, 22 \mathrm{~mm}$ and $22 \mathrm{~mm}$ but Entero. faecalis, S. enterica enterica (Typhimurium) and Shig. flexneri show high resistance for both alcoholic and aqueous extracts $8 \mathrm{~mm}, 9 \mathrm{~mm}, 8 \mathrm{~mm}, 0 \mathrm{~mm}, 12 \mathrm{~mm}, 10 \mathrm{~mm}$ compared to the sensitivity for ciprofloxacin : $23 \mathrm{~m}, 30 \mathrm{~mm}$ and $31 \mathrm{~mm}$, the results also showed that the most sensitive organism to both extracts was Pseudo. aeruginosa and the least sensitive organisme Entero. faecalis, then according to the results of dilution of alcoholic extract, the minimum inhibitory concentrations (MIC) sensitive microorganisms : Pseudo. aeruginosa (MIC=50 mg/ml), Staph. aureus (MIC=100 mg/ml) and Micro. luteus (MIC=100mg/ml). 


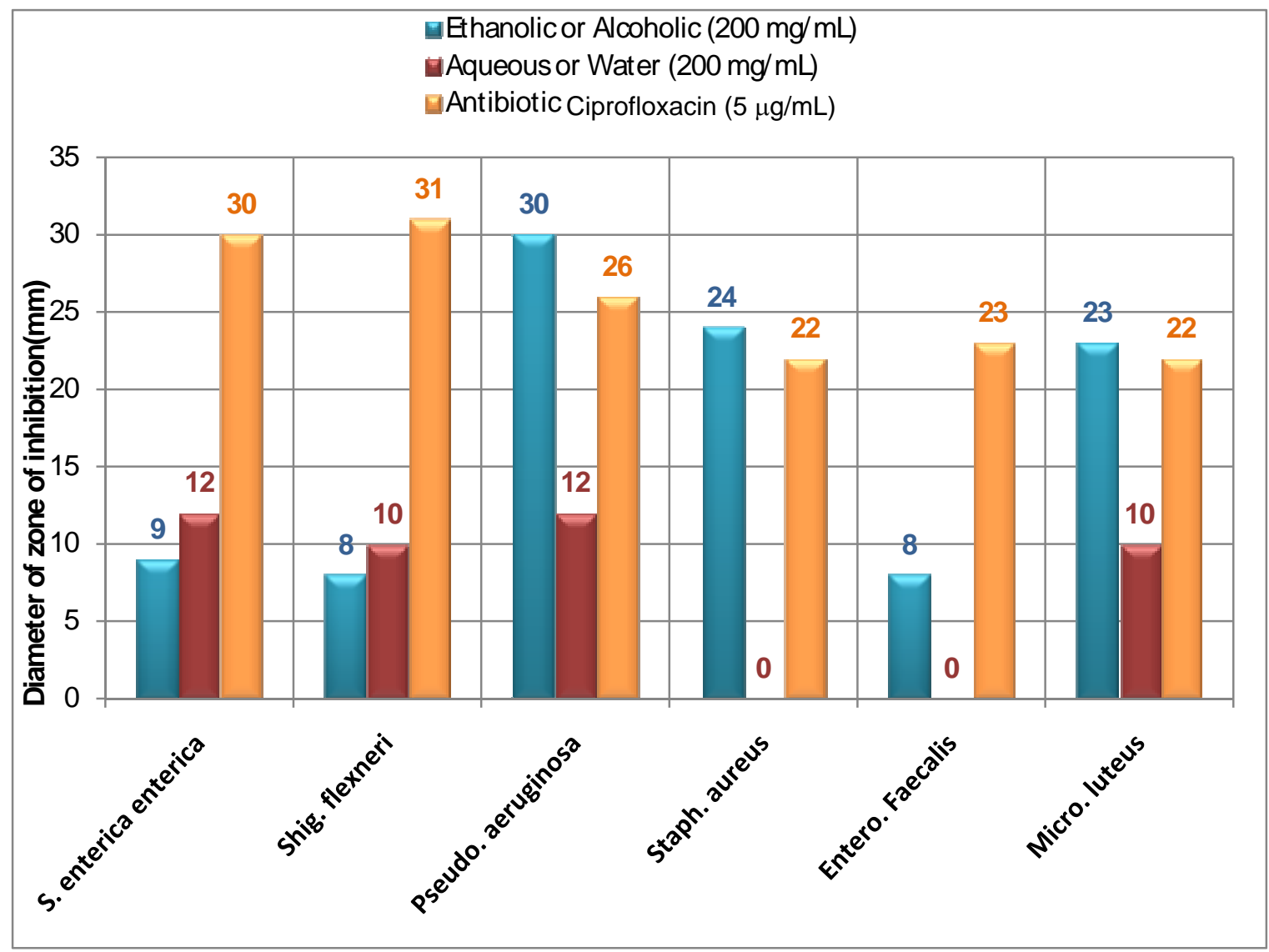

Fig. 2: Alcoholic and aqueous extract comparison with Ciprofloxacin.

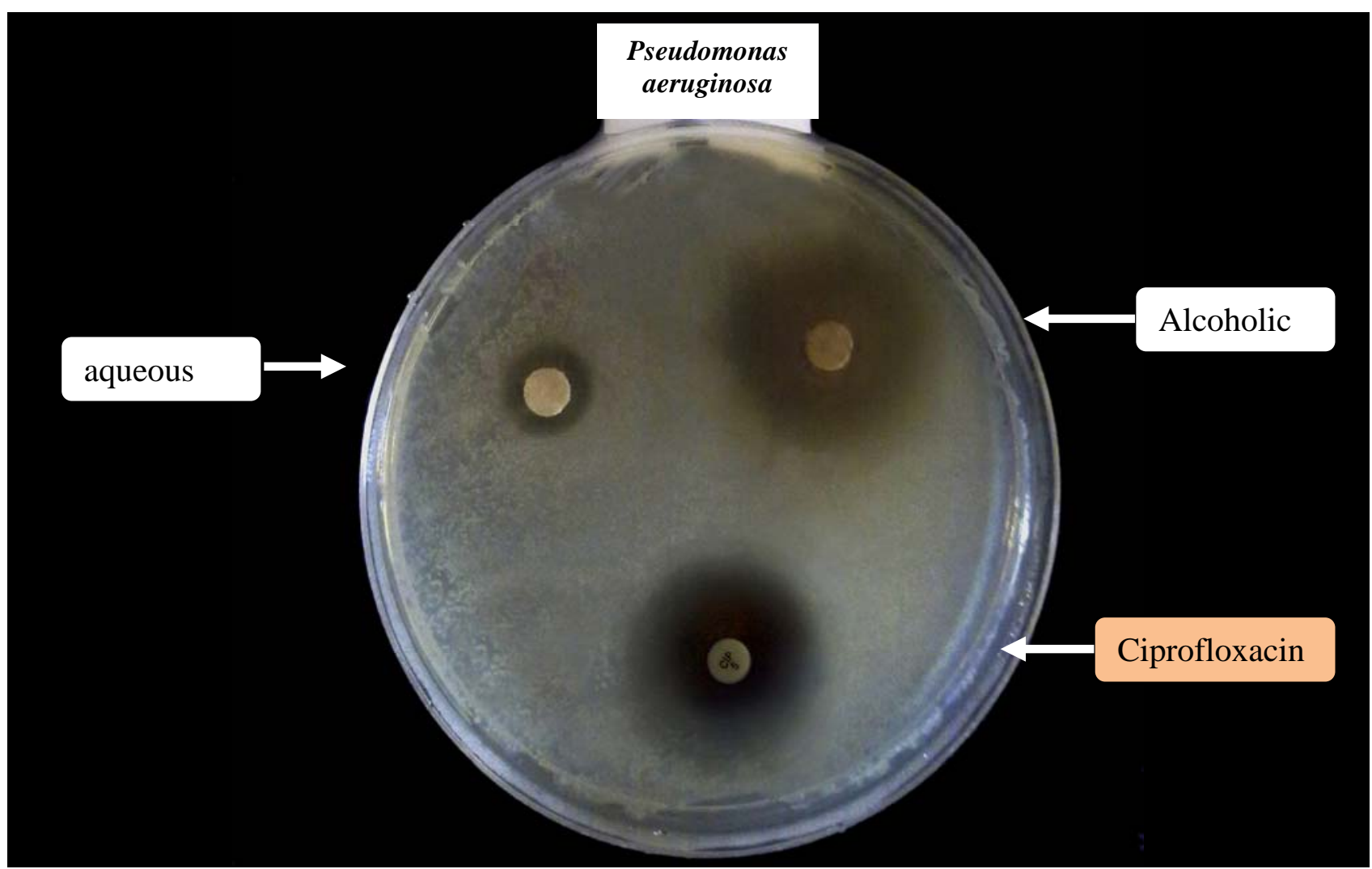

Pic. 1 : Pseudomonas aeruginosa 


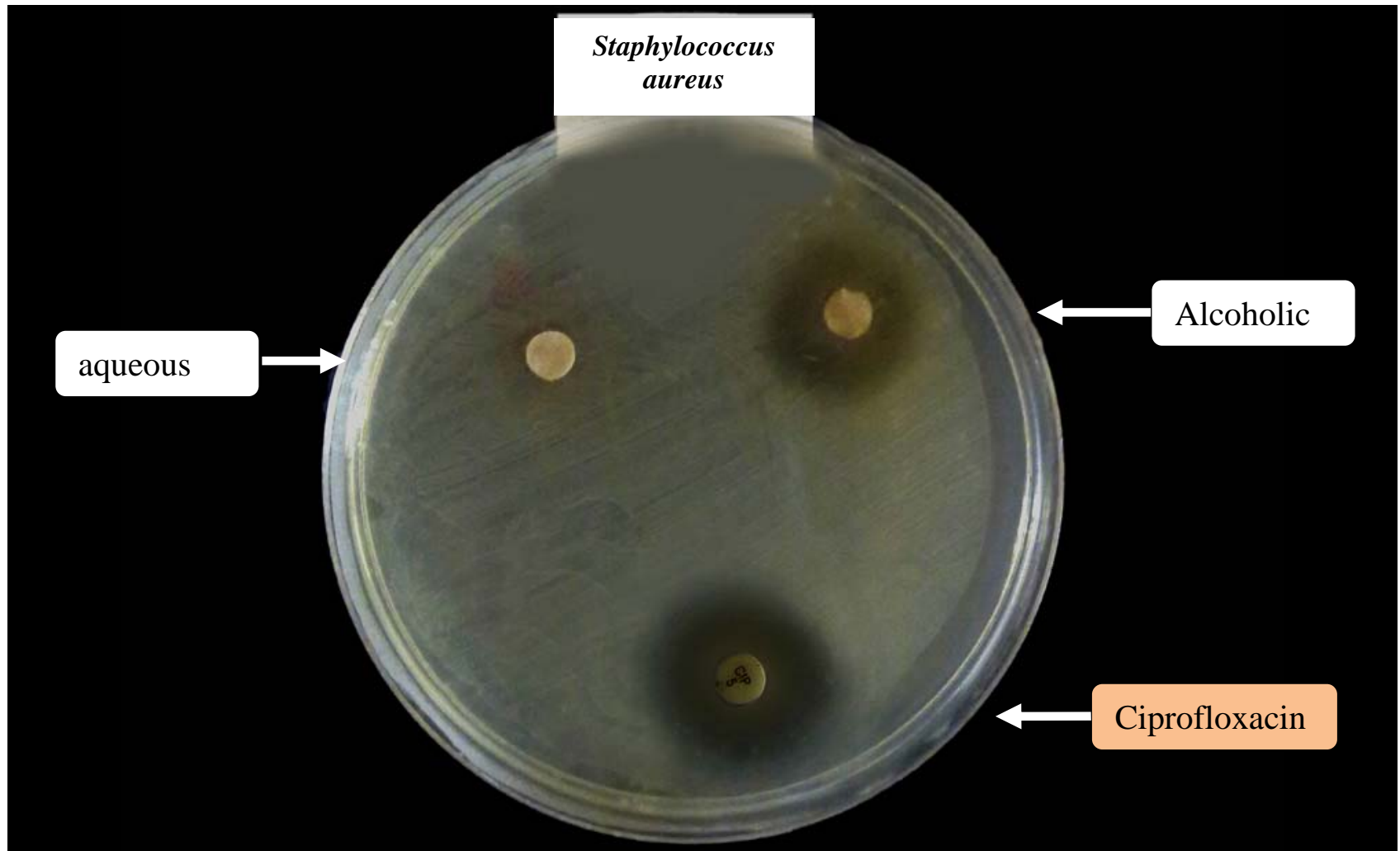

Pic. 2 : Staphylococcus aureus

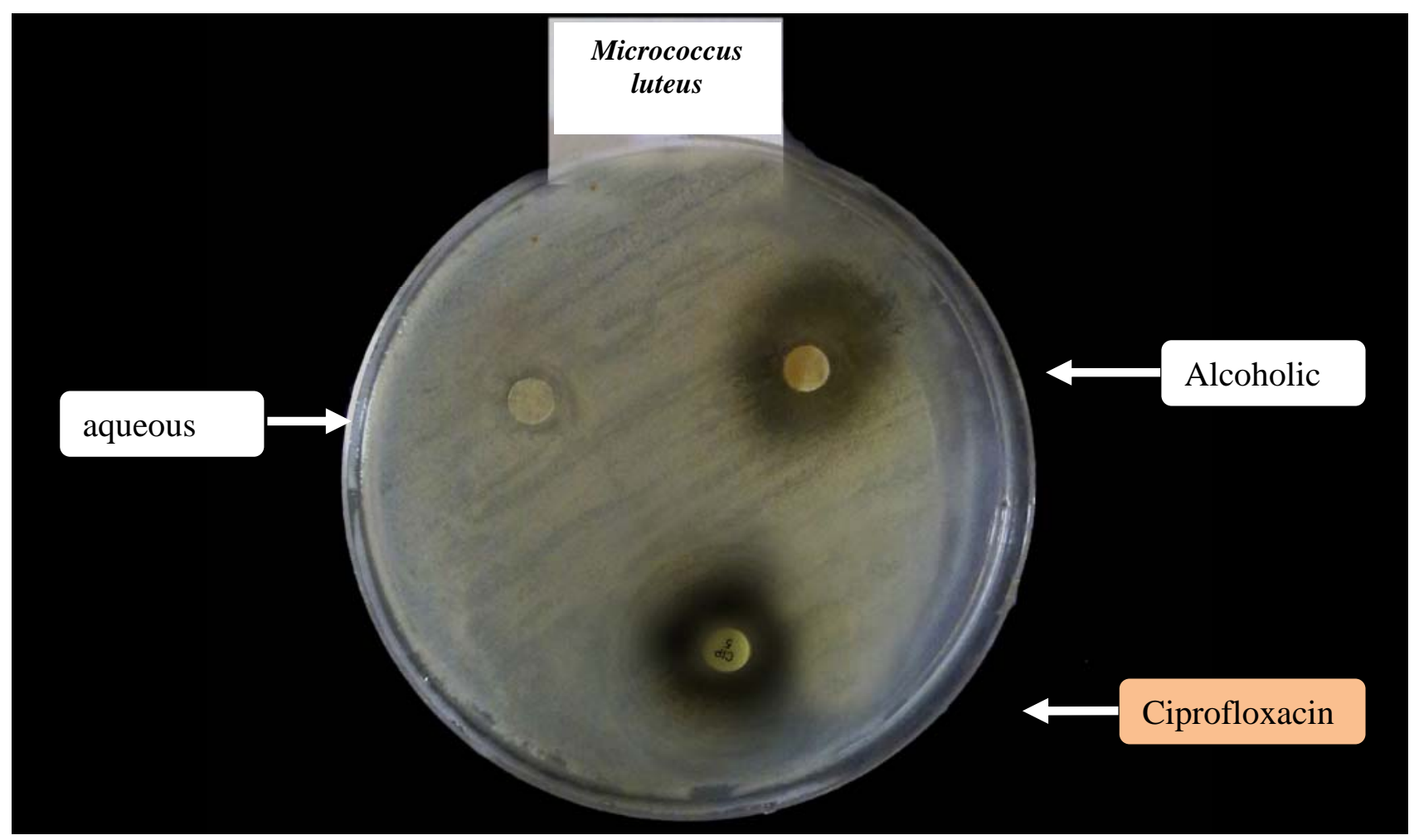

Pic. 3 : Micrococcus luteus 
The result of this study agreed with recent investigation which have also pointed out to the notable effect of extracts of aerial parts of yarrow as it showed a board spectrum antimicrobial activities against Staph. aureus, E. coli, K. pneumoniae, A. niger and C. albicans (Candan et al., 2003 ; Skoeibusic et al., 2004; Radulovic, 2005).

It could be concluded that the alcoholic extract of yarrow flower have considerable antibacterial effect on some pathogenic microorganisms which cause infections. Therefore, befor application of these extracts as antimicrobial agents it must be evaluated in vivo and clinically.

\section{CONCLUSION}

On the light of these finding and other reports in this field, it could be concluded that:

Yarrow flower extract have potential antibacterial effect against certain microorganisms which cause infections.

Possible benefits from other herbs with antibacterial activity. Further large - scale, well - designed clinical trails are required to prove more conclusive proof of their efficacy, the problem of microbial resistance is growing and the out look for use antimicrobial drugs in future is still uncertain, therefore, action must be taken to reduce this problem, control the use of antibiotic, develop research to better understand the genetic mechanisms of resistance and to continue studies to develop new drugs, either synthetic or natural. The aim is to offer appropriate and efficient antibacterial drugs to patient.

\section{REFERENCES}

Al - Joboory, A. ; Al - Rawi, M. (1994). "Natural Pharmacology". 1st edn. Baghdad, dar Al - Huriah.

$\mathrm{Al}$ - Neman, A.Y.S. (1998). The molecular effect of some plant extracts on the Growth and metabolism of some Gram positive and Gram negative Bacteria .Ph. D. thesis, College of Science, University of Mosul, Mosul, Iraq. (in Arabic)

Anonynous, B. (1993). World Health Organization Summary of WHO of guide liness for the assessment of herbal medicines Gram, (28),13-14.

Ates, A. ; Erdogrul, O.T. (2003). Antimicrobial activities of various medicinal and commercials plant extracts. Turk J. Biol., (27),157-162.

Atlas , R.M.; Brown, A.E.; Parks , L.C.(1995). "Experimental Microbiology" :laboratory manual ,Mosby-year. Book., Inc.

Baker, J.T.; Borris, R.P. ; Carte, B. (1995). Natural product drug discovery and development new perceptive on international collaboration. J. Nat. Prod., (58),1325-1325.

Barbour, E.K.; Sharif, M.A.; Sagherian, V.K.; Habre, A.N.; Talhouk, R.S ; alhouk, S.N. (2004). Screening of selected indigenous plants of Lebanon for antimicrobial activity. J. Ethnopharmacol.( 93) ,1-7.

Bisset, N. M. (1994). "Herbal Drugs and Photo Pharmaceuticals". CRC press London, 566p.

Candan, F.; Unlu, M.; Tepe, B.; Daferera, D.; Polissiou, M.; Sokmen, A. ; Akpulat, H.A. (2003). Antioxidant and antimicrobial activity of the essential oil and methanol extracts of Achillea millefolium subsp. millefolium Afan. (Asteraceae). J. Ethnopharmacol.,( 87), 215-220.

Chandler, R. F. ; Hooper, S.N. ; Harvey, M. J. (1982). Ethno botany and photochemistry of yarrow, Achillea millefolium, Composit. Entero. Econ. Bio.(36),03-223. 
Collins, C.M.; Lyne P.M. (1987). "Microbiological Methods Butterworth’s and Co(publishers) ". Ltd. London. 450 p.

Collee, J. G.; Fraser, A. G.; Marmion, B. P.; Simmons, A. (1996). "Mackie and McCartney Practical Medical Microbiology". 14th ed., Churchill Livingstone, New York.

Dulger, B.; Gonuz, A. ; Bican, T. (2005). Antimicrobial studies on three endemic species of sideritisform Turkey. Acta biological cracoviensia series botanic 47/2,153-156.

Evans , C. ; Bansot, A. ; Samuel, A. (2002). Efficacy of some nape medical plants against Salmenella: an in vitro study.J. Ethnopharmacol. (80),12-24.

Finch, R. G. (1998). Antibiotic resistance. J. Antimicrobial chemotherapy (42) ,125-128.

Hirti, U. (2000). Phyotherapie bei der KatzEntero. Anwendungsmoglichkeiten und Anwendungshaufigkeiten durch den Besitzer. Dissertation, Vet. Med.Univ. Wien.

Iwu, M. W.; Duncan, A.R.; Okunji, C.O. (1999). New antimicrobial of plant origin. Janick J.(Ed) Perspectives New Crops and New Uses. ASHS press, Alexandra 457-462.

Kirbag, S.; Kursat, M.; Zengin, A. (2005). Elazig da tibbi amaclar icin kullanilan bazi bitki extraklarinin antimicrobial aktiviterleri. Dogu anadolu bolgest arastirmalari: 168171.

Kivcak, B. ; Mert, T. ; Ozturk, H.T. (2002). Antimicrobial and cytotoxic activities of cerratonia siliqua L. extracts. Turk J. Biol., (26),197-200.

Kumar, P.V.; Chauhan, S.N.; Padh, H.; Rajani, M. (2006). Search for antimicrobial and antifungal agents from selected Indian medicinal plants. J. Ethnophar-macology, (107),182-188.

Kunin, C.M. (1993). Resistance to antimicrobial drugs a world-wide calamity. Annals of Internal. Medi. , (118), 557-561.

Ludwing, M. (1996). Phytotherapie biem Rind einst und Jetzt -Alte indikationen neu bewertet . Dissertation, Vet. Med.Univ. Wien .

Mahansen, A. (1996). Antimicrobial activity of extracts of herbal plants used in the traditional medicine of Bahrain. Phototh. Research,(10), 252-253.

Mathabe, M.C.; Nikolova, R.V.; Nyazema, N.Z. (2006). Antimicrobial activities of medicinal plants used for the treatment of diarrhoea in Limpopo Province, south Africa, J. Ethno Pharmacol., (107), 286-293.

Muller, J. B.; Breu, W.; Probstle, A. (1994). In vitro inhibition of cyclooxygenase and 5lipoxygenase by alkamides from Echinacea and Achillea species. Plants Med., (60), 37-40.

Nair, R.; Kaalariye, T.; Chanda, S. (2005). Antimicrobial activity of some selected Indian medicinal flora. Turk J. Biol., (29 ), 41- 47.

Najla, A.K. ; Awaz, F. (2009). Isolation and antibacterial evaluation of plant extracts from some medical plants in Kurdistan region. J. Duhok Univ. 12, (1) (Special Issue) , 250-255.

Nascimento, L. (2000). Antibacterial Activity of Plant Extract and Photochemical on Antibiotic- resistant bacteria. Braz. J. micro. (31), 247-256.

Nemeth, E., Bernath, J. (2008). Biological activities of yarrow species (Achillea spp.). J. Ethno pharmacology, 101, Issues 1-3 , 185-190.

Pattnak, S. (1997). Antimicrobial and antifungal activity of aromatic constituents of essentials oils. Micro bios. (89), 39-46.

Penlope, A. (1999). "The Complete Medicinal Herbal". Academic international, Beirut, Lebanon, for publishing and printing. 30 p.(In Arabic) 
Radulovic, N.; Hashimoto, T. ; Pali, R. (2005). In vitro antimicrobial activity of extracts of four Achillea species: The composition of Achillea clavennae L. (Asteraceae) extract. J. Ethno pharmacol. (101),185-190.

Romero, E. (2005). Antibacterial properties of common herbal remedies of the Southwest. J. Ethnoharm. 2(99), 253-257.

Sengul, M.; Ogutcu, H. (2005). Antimicrobial effect of verb scum georgicum bentham extract. Turk J. Biol., (29),105-110.

Skoeibusic, M.; Bezi, N.; Dunki, V.; Radoni, A. (2004). Antibacterial activity of Achillea clavenn essentials oil against respiratory tract pathogens. Phototherapy, (75),733736.

Tindall, B.J.; Grimont, P.A.D.; Garrity, G.M.; Euzeby, J.P. (2005). Nomenclature and taxonomy of the genus Salmonella. Intern. J. Syst. and Evo. Microbiol., (55), 521524.

WHO Global Foodborne Infections Network. Laboratory Protocol: "Biochemical Identification of Salmonella/ shigella using an Abbreviated Panal of tests", January, (2010). Available at: http//www.antimicrobialresistancEntero.dk/data/ images/protocols/gfn_biochem_final.pdf.

Uzun, Y.; Keles, A.; Imali, A.; Ogun, E. ; Kaya, A. (2002). Antimicrobial activity of Urtica dioica L. and Rheum ribes L. , Bio- science research bulletin, (18) , 43-50. 